\title{
PENGGUNAAN SAW UNTUK ANALISIS PROSES PEREBUSAN KEDELAI DALAM PRODUKSI TEMPE
}

\author{
Dana Marsetiya Utama*, Teguh Baroto \\ Jurusan Teknik Industri, Fakultas Teknik, Universitas Muhammadiyah Malang \\ Email: $\underline{\text { dana@umm.ac.id }}$
}

\begin{abstract}
This article describes assessment organoleptic quality in boiling process soybean at production tempe. we proposed the model for selecting boiling process soybean based on quality organoleptic. We used pairwise comparison and SAW the problem. Pairwise comparison used to determine to weigh for organoleptic criteria. SAW used for selecting boiling process alternative. the result of proposed pairwise comparison and SAW model showed this model effective for assessment organoleptic quality in boiling process soybean at production tempe.
\end{abstract}

\section{Keywords: AHP, SAW, Tempe, Quality}

\section{PENDAHULUAN}

Tempe kedelai adalah salah satu makanan tradisional yang sangat digemari. Tempe adalah satu bahan makanan dengan kandungan protein tinggi (Shurtleff and Aoyagi, 1979). Tempe dihasilkan dari fermentasi jamur rhizopus oligosporus dengan bahan kacangkacangan (Haliza et al., 2016). Pada tahap fermentasi, kacang-kacangan dicampur dengan ragi tempe (rhizopus oligosporus). Hasil fermentasi tersebut membentuk padatan putih. Miselia jamur yang tumbuh pada permukaan biji kacang-kacangan menyebabkan warna putih pada tempe (Halifah, 2011). Vitamin, mineral, serat, lemak, dan karbohidrat adalah gizi yang terkandung dalam tempe (Utari, 2010). Kacang kedelai adalah salah satu bahan makanan dengan kandungan protein nabati yang baik (Ginting et al., 2009). Terdapat beberapa manfaat tempe kedelai untuk kesehatan diantaranya: (a) mencegah terjadinya penyakit jantung; (b) menurunkan kadar kolesterol dalam darah dan mampu; (c) mempercepat proses penyembuhan duodenitis; (d) memperlancar pencernaan; (e) mencegah dan mengendalikan diare; (f) mengurangi toksisitas; (g) mencegah anemia; (h); meningkatkan vitalitas (i) menghambat ketuaan; (j) menghambat resiko diabetes mellitus; (k) menghambat resiko jantung dan kanker; (l) sebagai antibiotik (Hidayat, 2009).

Menurut Ristia et al. (2014), untuk memproduksi tempe yang berkualitas, beberapa yang perlu diperhatikan yaitu: (a) meminimalisir terjadinya pencemaran dan juga kontaminasi tiap tahapan proses pembuatan; (b) lama perebusan kedelai; (c) meniriskan hasil perebusan kedelai dengan baik sebelum proses inokulasi (penambahan ragi); (c) fermentasi tempe perlu dikendalikan dengan baik pada suhu $30-35^{\circ}$ C. Beberapa penelitian tetang kualitas pangan telah banyak diteliti. Umumnya kualitas pangan diteliti dari kualitas fisik-kimiawi dan organoleptik (Widjanarko et al., 2012, Resnawati, 2014, Wahyuni, 2011). Pada kualitas fisikkimiawi diperlukan uji laboratorium untuk mengetahui nilai dari parameter-parameter (protein, lemak, kabohidrat, dll) yang di uji. Sedangkan pada kualitas organoleptik pengujian berdasarkan preferensi responden terhadap (rasa, aroma, warna, dll). Pengujian kualitas organoleptik 
mempunyai beberapa keuntungan diantaranya lebih cepat dan biaya yang lebih terjangkau.

Parameter organoleptik masuk dalam multi criteria karena memiliki beberapa parameter. Multiple Criteria Decision Analysis (MCDA) adalah sebuah topik yang dijelaskan dalam bidang sistem pakar. MCDA merupakan suatu metode pengambilan keputusan untuk menetapkan alternatif terbaik dari sejumlah alternatif berdasarkan beberapa kriteria tertentu. Pemilihan alternatif berdasarkan beberapa kriteria cocok untuk penyelesaian pengambilan keputusan. Penggunaan skala preferensi memudahkan dalam pengambilan keputusan. Banyak peneliti menggunakan MCDA untuk menyelesaikan masalah pengambilan keputusan yang kompleks (AlemiArdakani et al., 2016, Mardani et al., 2015). Beberapa peneliti telah mengusulkan beberapa metode untuk masalah pengambilan keputusan diantaranya adalah ELECTRE (Roy, 1968), PROMETHEE (Brans and Vincke, 1985), AHP (Saaty, 1990), TOPSIS (Lai et al., 1994), VIKOR (Opricovic and Tzeng, 2004), SUR (Li et al., 1997), integrasi AHP-TOPSIS (Abiddin et al., 2017) dan SAW (Afshari et al., 2010).

Beberapa penelitian telah banyak dilakukan untuk uji kualitas organoleptik pangan. Namun, umumnya tidak memperhatikan bobot dari parameter uji organoleptik. Penentuan bobot dari parameter uji organoleptik termasuk dalam masalah MCDA. Tujuan penelitian ini adalah menggunakan teknik pairwise comparison dan SAW untuk menentukan waktu perebusan kedelai produksi tempe yang optimal. Proses perebusan kedelai tempe manggukanan high pressure cooker. Metode pairwise comparison digunakan untuk mengetahui bobot dari tiap-tiap parameter kualitas uji organoleptik dan SAW digunakan untuk mengetahui tingkat preferensi responden terhadap kuaitas organoleptik berdasarkan alternatif lama perebusan.

\section{BAHAN DAN METODE}

\section{Bahan dan Alat}

Dalam penelitian ini, kami menggunakan alat perebusan high presure dengan dimensi 100x80X80 cm. Kedelai yang digunakan adalah jenis kedelai GMO import. Setiap kali perebusan menggunakan $75 \mathrm{~kg}$ kedelai dan 150 liter air. Prosedur perebusan kedelai pada produksi tempe adalah (1) siapkan kacang GMO pilihan, (2) Biji kacang kedelai selanjutnya dicuci bersih sampai air terlihat jernih, (3) kedelai di direndam selama 1 malam, (4) kedelai di rebus berdasarkan lama perebusan yang ditetapkan sebagai kontrol.

\section{Metode Pengukuran, pengujian}

Kami menggunakan 2 eksperimental dengan mengubah besaran variabel bebas (lama perebusan) kemudian dicari hubungan atau pengaruhnya terhadap variabel organoleptik (kelunakan, rasa, tekstur, aroma dan warna). variabel bebas yang digunakan adalan lama perebusan yang terdiri dari 2 perlakuan. Perlakuan pertama adalah lama perebusan kedelai 2 jam. Perlakukan kedua adalah lama perebusan kedelai 3 jam. Penelitian ini mengusulkan 3 tahapan penelitian dalam pengujian kualitas perebusan kedelai produksi tempe (Gambar 1).

\section{Tahap 1 : Penentuan kriteria}

Langkah penting dalam MCDA adalah penentuan kriteria. Tahap pertama adalah membentuk tim panel untuk menentukan kriteria. Tim melakukan kajian literatur untuk mendapatkan kriteria uji organoleptik. Penelitian ini dilakukan dengan menggunakan 5 kriteria uji organoleptik. Lima kriteria itu adalah Warna, Rasa, Tekstur, Aroma dan Bentuk (Tabel 1). 
Tabel 1. Identifikasi kriteria uji organoleptik

\begin{tabular}{ll}
\hline kriteria uji organoleptik & \multicolumn{1}{c}{ Sumber } \\
\hline \multirow{2}{*}{ Warna } & Wahyuni (2011), Juwita et al. (2013), Hadiwijaya (2013), \\
& Sisriyenni and Zurriyati (2014) \\
Rasa & Wahyuni (2011), Hadiwijaya (2013), Sisriyenni and \\
& Zurriyati (2014), Winarti et al. (2011) \\
Tekstur & Mappa et al. (2013), Winarti et al. (2011) \\
Aroma & Wahyuni (2011), Hadiwijaya (2013), Mappa et al. (2013), \\
Bentuk & Sisriyenni and Zurriyati (2014) \\
& Mappa et al. (2013) \\
\hline
\end{tabular}

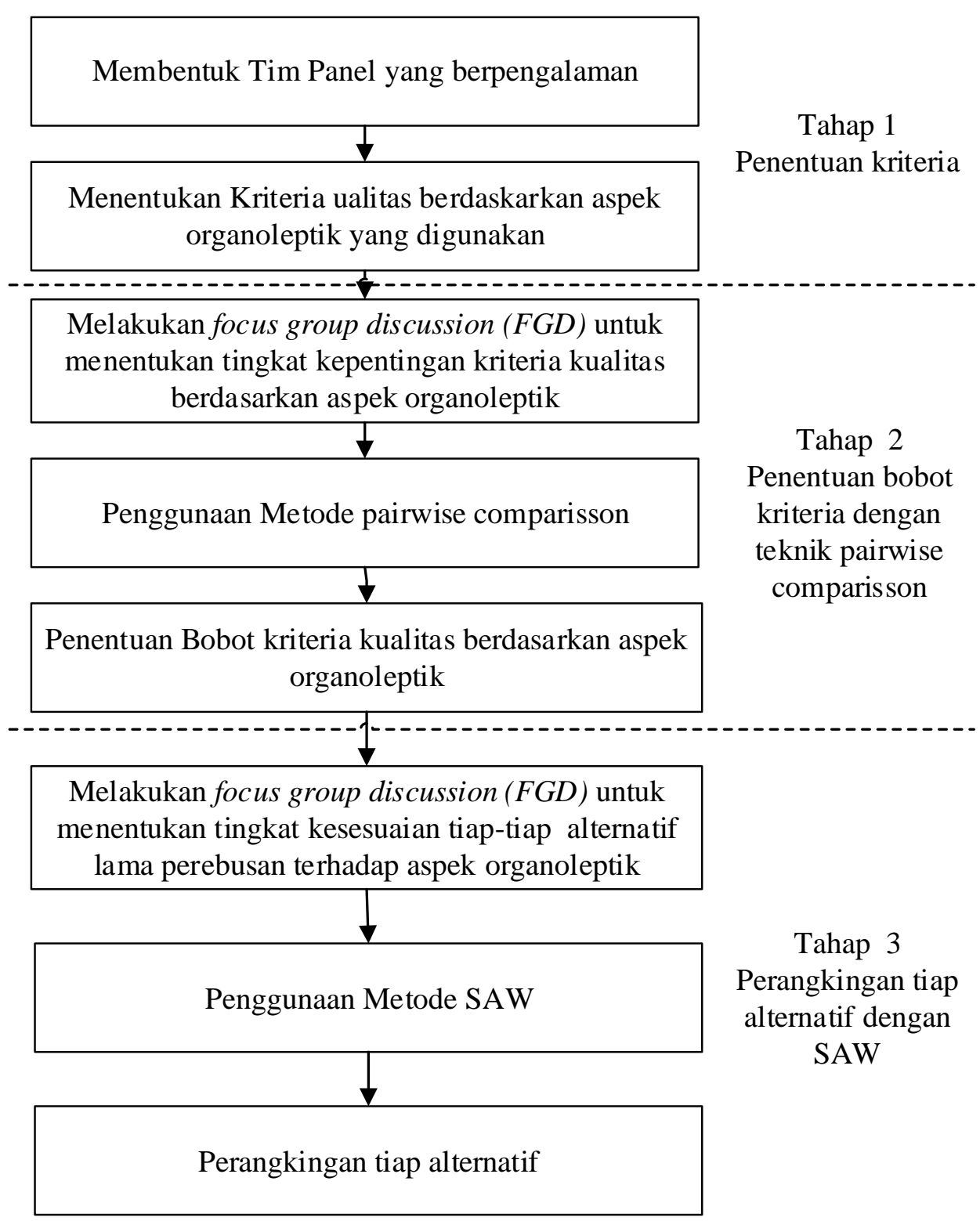

Gambar 1. Kerangka usullan pengujian kualitas 


\section{Tahap 2 : Pairwise Comparison}

Teknik pairwise comparison diusulkan oleh Saaty (1990). Tahapan pertama dalam teknik pairwise comparison adalah membuat matriks perbandingan berpasangan tiap-tiap kriteria (Matriks A). Perbandingan berpasangan didasarkan pada skala penilaian sembilan tingkat. Skala (1) menunjukan kedua kriteria sama penting, Skala (3) menunjukan salah satu kriteria sedikit lebih penting, (5) menunjukan salah satu kriteria lebih penting, (7) menunjukan salah satu kriteria jelas lebih penting, dan (9) menunjukan salah satu kriteria mutlak lebih penting. Perbandingan berpasangan dari $\mathrm{n}$ kriteria diringkas dalam matriks penilaian berpasangan nxn. Matriks perbandingan berpasangan A dapat dilihat pada persamaan 1. Notasi aij menunjukan penilaian numerik dari perbandingan berpasangan antara kriteria $\mathrm{i}$ dan $\mathrm{j}$. Misalnya, jika kriteria i mutlak lebih penting atas kriteria $\mathrm{j}$, maka aij $=9$, dan jika sebaliknya aji= 1/9 (lihat persamaan 2). Langkah selanjutnya dalam teknik pairwise comparison adalah menormalkan dan memperoleh bobot dari matriks A. Penormalan dilakukan dengan membagi nilai kolom dengan jumlah kolom. Prinsip dari eigen vektor dapat dilihat di persamaan 3. Langkah terakhir dalam teknik pairwise comparison adalah melakukan perhitungan konsistensi (lihat persamaan 4 dan 5).

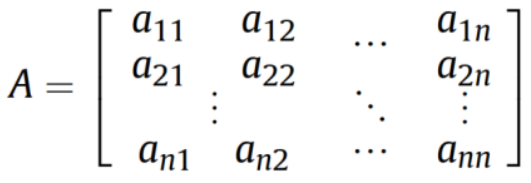

$$
\begin{aligned}
& a_{i j} \neq 0, \quad a_{i i}=1, \quad a_{j i}=\frac{1}{a_{i j}} \\
& A w=\lambda_{\max } w
\end{aligned}
$$

$$
\begin{aligned}
& C I=\frac{\lambda_{\max }-n}{n-1} \\
& C R=\frac{C I}{R I}
\end{aligned}
$$

Tahap 3 : Perangkingan alternatif dengan metode $\mathrm{SAW}$

Perangkingan alternatif lama perebusan yang sesuai menggunakan metode simple additive weighting (SAW). SAW memerlukan kriteria dan nilai bobot yang menjadi bahan perhitungan dalam proses perangkingan. Pembobotan kriteria uji kualitas telah dilakukan menggunakan AHP. Secara umum tedapat 5 tahapan SAW. Tahapanya adalah (1) membuat peringkat dari masing-masing alternatif pada tiap kriteria. Skala peringkat yang digunakan adalah 1-5. Skala 1 menunjukan sangat tidak puas, 2 menunjukan tidak puas, 3 menunjukan cukup puas, 4 menunjukan puas dan 5 menunjukan sangat puas. Tahap 2 adalah Membuat matriks keputusan X (lihat persamaan 6), yang dibentuk dari Tabel peringkat kesesuaian masing-masing alternatif pada setiap kriteria. Nilai (X) setiap alternatif (Ai) pada setiap kriteria $(\mathrm{Cj})$ yang telah ditentukan, dimana, $\mathrm{i}=1,2, \ldots \mathrm{m}$ dan $\mathrm{j}=$ $1,2, \ldots$. . Tahap 3 adalah melakukan normalisasi matriks keputusan dengan menghitung nilai-nilai kinerja ternormalisasi (rij) dari Ai alternatif pada kriteria $\mathrm{Cj}$ (lihat persamaan 7). Tahap 4 adalah membentuk matriks normalisasi (R) berdasarkan nilai rij (lihat persamaan 8). Tahap 5 adalah melakukan penjumlahan dari perkalian matriks ternormalisasi $\mathrm{R}$ dengan bobot kriteria (lihat persamaan 9). nilai terbesar yang dipilih sebagai alternatif terbaik sebagai solusi. 


$$
\begin{aligned}
& X=\left[\begin{array}{ccc}
X_{11} X_{12} & \cdots & X_{1 j} \\
\vdots & & \vdots \\
X_{i 1} X_{i 2} & \cdots & X_{i j}
\end{array}\right] \\
& r i j=\left\{\begin{array}{c}
r i j=\frac{x i j}{M a x x i j} \text { jika j adalah atribut keuntungan (benefit) } \\
\text { rij }=\frac{M i n x i j}{x i j} \text { jika j adalah atribut biaya (cost) }
\end{array}\right. \\
& R=\left[\begin{array}{ccc}
r_{11} r_{12} & \cdots & r_{1 j} \\
\vdots & & \vdots \\
r_{i 1} r_{i 2} & \cdots & r_{i j}
\end{array}\right] \\
& V i=\sum_{j=1}^{n} w j r i j
\end{aligned}
$$

\section{HASIL DAN PEMBAHASAN \\ Hasil Pembobotan Kriteria Uji kualitas Organoleptik dengan Teknik pairwise comparison}

Hasil penentuan kriteria yang digunakan untuk uji kualitas organoleptik selanjutnya melakukan focus group discussion. Focus group discussion dilakukan 6 orang $(2$ perwakilan konsumen, 2 pengusaha dan 2 pakar). Tabel 2 menunjukan hasil focus group discussion dari tingkat kepentingan tiaptiap kriteria organoleptik dengan menggunakan matriks pairwise comparison. Perhitungan pairwise comparison dilakukan dengan bantuan software expert choice 11. Hasil perhitungan pairwise comparison untuk mencari bobot kriteria dapat diliat pada Tabel 3.

Dari Tabel 3 menunjukan bobot untuk kriteria uji organoleptik berdasarkan teknik pairwise comparison dari rangking tertinggi ke terendah adalah Rasa mempunyai bobot tertinggi dengan bobot 0.484 . Tekstur dengan bobot 0,189 . Ketiga yaitu Aroma dengan bobot 0.189. Keempat yaitu Bentuk dengan bobot 0.072. Dan Warna dengan bobot 0.066. Dari hasil penelitian menunjukan bahwa rasa mempunyai bobot yang paling tinggi. Hal ini menunjukan bahwa rasa menjadi faktor paling penting dalam uji organoleptik. Rasa mempunyai bobot kriteria paling tinggi karena menjadi faktor utama konsumen dalam memilih makanan. Semakin baik rasa dari makanan, maka kecenderungan konsumen untuk memilih/membeli makanan semakin besar. Sehingga rasa menjadi faktor paling penting sesuai dengan penelitian yang dilakukan oleh Mulyadi et al. (2014). Sedangkan bentuk menjadi kriteria yang kurang di pentingkan dari uji organoleptik. Hal ini disebabkan karena bentuk kedelai akan mengalami transformasi ke bentuk tempe. Ketika kedelai dilakukan fermentasi, bentuk tidak lagi menjadi faktor yang dipentingkan oleh konsumen/pelanggan. Bentuk berkontribusi kecil terhadap preferensi konsumen/pelanggan untuk memilih produk. Sehingga bentuk kurang di pentingkan dalam uji kualitas organoleptik (Astuti, 2009). 
Tabel 2. matriks pairwise comparison kriteria uji organoleptik

\begin{tabular}{lccccc}
\hline $\begin{array}{l}\text { kriteria uji } \\
\text { organoleptik }\end{array}$ & Warna & Rasa & Tekstur & Aroma & Bentuk \\
\hline Warna & 1 & 7 & 3 & 3 & 1 \\
Rasa & $1 / 7$ & 1 & 3 & 3 & 5 \\
Tekstur & $1 / 3$ & $1 / 3$ & 1 & 1 & 3 \\
Aroma & $1 / 3$ & $1 / 3$ & 1 & 1 & 3 \\
Bentuk & 1 & $1 / 5$ & $1 / 3$ & $1 / 3$ & 1 \\
\hline
\end{tabular}

Tabel 3 Bobot dan rangking kriteria uji organoleptik berdasarkan AHP

\begin{tabular}{lcc}
\hline kriteria uji organoleptik & Bobot & Rangking \\
\hline Warna & 0.066 & 5 \\
Rasa & 0.484 & 1 \\
Tekstur & 0.189 & 2 \\
Aroma & 0.189 & 3 \\
Bentuk & 0.072 & 4 \\
\hline
\end{tabular}

\section{Hasil perangkingan alternatif lama perebusan dengan Metode SAW}

Hasil pembobotan AHP (Tabel 3) digunakan sebagai bobot kriteria dalam penentuan lama perebusan dengan menggunakan metode SAW. Metode SAW ini digunakan untuk perangkingan lama perebusan optimal berdasarkan kualitas uji organoleptik. Perangkingan alternatif lama perebusan dengan metode simple additive weighting memerlukan kriteria dan nilai bobot sebagai input perhitungan dalam proses perangkingan. Untuk membuat peringkat kecocokan masing-masing alternatif pada setiap kriteria dilakukan dengan focus group discussion. Hasil focus group discussion peneliaian kesesuaian masing-masing alternatif pada setiap kriteria dapat dilihat pada Tabel 4 (lihat persamaan 6). Nommalisai untuk tiap-tiap kriteria Warna, Rasa, Tekstur, Aroma dan Bentuk menggunakan $\mathrm{rij}=(\mathrm{xij}) /($ Max xij $)$ karena jika tiap-tiap kriteria adalah atribut keuntungan (lihat persamaan 7). Hasil normalisasi matriks keputusan nilai-nilai kinerja ternormalisasi (rij) dari alternatif pada tiap-tiap kriteria dapat dilihat pada
Tabel 5 (lihat persamaan 8). Untuk mendapatkan rangking alternatif lama perebusan dilakukan penjumlahan dari perkalian matriks ternormalisasi dengan bobot kriteria seperti persamaan 9. Hasil perangkingan alternatif lama perebusan dapat dilihat pada Tabel 6.

Tabel 6 menunjukan hasil pengolahan data dengan metode SAW yang didapatkan hasil akhir rangking untuk tiap alternatif lama perebusan. Berdasarkan tingkat preferensi alternatif lama perebusan terhadap kualitas uji organoleptik didapatkan hasil akir rangking untuk tiap alternatif lama perebusan pertama didapatkan 2 Jam dengan total preferensi 0.982. Rangking kedua adalah alternatif lama perebusan 3 jam dengan total preferensi 0.694. Hasil ini menunjukan semakin lama proses perebusan menunjukan kualitas organoleptik semakin buruk. Hal ini sesuai dengan penelitian yang dilakukan oleh Halifah (2011) dan Dwi Saputri and Arum (2009). Penggunaan teknik pairwise comparison dan SAW efisien digunakan untuk pemilihan waktu perebusan kedelai dalam 
produksi tempe. Penggunaan teknik alternatif. Sehingga perhitungan pairwise pairwise comparison dan SAW lebih comparison dan SAW lebih mudah efisien karena menggunakan tingkat dibandingkan tools MCDA yang lain preferensi pada tiap-tiap kriteria dan seperti Promethee, Electre, dan Topsis.

Tabel 4 Penilaian kesesuaingan masing-masing alternatif pada setiap kriteria

\begin{tabular}{cccccc}
\hline \multirow{2}{*}{$\begin{array}{c}\text { Alternatif Lama } \\
\text { Perebusan }\end{array}$} & Warna & Rasa & Tekstur & Aroma & Bentuk \\
& 0.066 & 0.484 & 0.189 & 0.189 & 0.072 \\
\hline 2 Jam & 4 & 4 & 4 & 3 & 2 \\
3 Jam & 3 & 2 & 3 & 3 & 4 \\
\hline
\end{tabular}

Tabel 5 Hasil normalisasi pada tiap-tiap kriteria

\begin{tabular}{cccccc}
\hline & \multicolumn{5}{c}{ Uji Organoleptik } \\
\cline { 2 - 6 } Alternatif Lama & Warna & Rasa & Tekstur & Aroma & Bentuk \\
Perebusan & 0.066 & 0.484 & 0.189 & 0.189 & 0.072 \\
\hline 2 Jam & 1 & 1 & 1 & 1 & 0.75 \\
3 Jam & 0.75 & 0.5 & 0.75 & 1 & 1 \\
\hline
\end{tabular}

Tabel 6 Hasil perangkingan alternatif lama perebusan terhadap kualitas uji organoleptik

\begin{tabular}{ccc}
\hline Rangking & $\begin{array}{c}\text { Alternatif Lama } \\
\text { Perebusan }\end{array}$ & Vi \\
\hline 1 & 2 Jam & 0.982 \\
2 & 3 Jam & 0.694 \\
\hline
\end{tabular}

\section{KESIMPULAN}

Penggunaan teknik pairwise comparison menghasilkan rasa sebagai kriteria yang dipentingkan oleh konsumen. Semakin baik rasa dari makanan, maka kecenderungan konsumen untuk memilih/membeli makanan semakin besar. Sehingga rasa menjadi faktor paling penting. Pada penilihan alternatif menggunakan SAW menunjukan semakin lama proses perebusan menunjukan kualitas organoleptik semakin buruk. Penggunaan teknik pairwise comparison dan SAW efisien digunakan untuk pemilihan waktu perebusan kedelai dalam produksi tempe. Pemilihan menggunakan tingkat preferensi pada tiap-tiap kriteria dan alternatif. Untuk penelitian selanjutnya, dapat menambahkan beberapa kriteria dalam uji organoleptik. Saran selanjutnya adalah menggunakan metode ANP untuk mengetahui bobot kriteria uji organoleptik.

\section{UCAPAN TERIMAKASIH}

Ucapan terimakasih kepada KEMENRISTEKDIKTI yang telah membiayai program Pengabdian Kepada Masyarakat Tahun Anggaran 2018 sesuai dengan surat nomor: 0047/E3/LL/2018.

\section{DAFTAR PUSTAKA}

Abiddin, M. Z., Mas'udin, I. \& Utama, D. M. 2017. Pemilihan Strategi Pemasaran Dengan Metode SWOT Dan TOPSIS. 2017, 18, 13. 
Afshari, A., Mojahed, M. \& Yusuff, R. M. 2010. Simple additive weighting approach to personnel selection problem. International Journal of Innovation, Management and Technology, 1, 511.

Alemi-Ardakani, M., Milani, A. S., Yannacopoulos, S. \& Shokouhi, G. 2016. On the effect of subjective, objective and combinative weighting in multiple criteria decision making: A case study on impact optimization of composites. Expert Systems with Applications, 46, 426-438.

Astuti, N. P. 2009. Sifat Organoleptik Tempe Kedelai yang Dibungkus Plastik, Daun Pisang dan Daun Jati. Universitas Muhammadiyah Surakarta.

Brans, J.-P. \& Vincke, P. 1985. Note-A Preference Ranking Organisation Method: (The PROMETHEE Method for Multiple Criteria DecisionMaking). Management science, 31, 647-656.

Dwi Saputri, S. \& Arum, K. 2009. Pengaruh lama pemasakan dan temperatur pemasakan kedelai terhadap proses ekstraksi protein kedelai untuk pembuatan tahu.

Ginting, E., Antarlina, S. S. \& Widowati, S. 2009. Varietas unggul kedelai untuk bahan baku industri pangan. Jurnal Litbang Pertanian, 28, 79-87.

Hadiwijaya, H. 2013. Pengaruh perbedaan penambahan gula terhadap karakteristik sirup buah naga merah (Hylocereus polyrhizus). Jurnal. Fakultas Teknologi Pertanian. Universitas Andalas.

Halifah, P. 2011. Pengaruh lama perebusan terhadap kadar protein tempe kacang tunggak (Vigna unguiculata). bionature, 12 .
Haliza, W., Purwani, E. Y. \& Thahir, R. 2016. Pemanfaatan kacang-kacangan lokal sebagai substitusi bahan baku tempe dan tahu. Buletin Teknologi Pasca Panen, 3, 1-8.

Hidayat, N. 2009. Tahapan proses pembuatan tempe, Malang. Indonesia, Universitas Brawijaya.

Juwita, A. P., Yamlean, P. V. \& Edy, H. J. 2013. Formulasi Krim Ekstrak Etanol Daun Lamun (Syringodium isoetifolium). Pharmacon, 2.

Lai, Y.-J., Liu, T.-Y. \& Hwang, C.-L. 1994. Topsis for MODM. European Journal of Operational Research, 76, 486-500.

Li, C., Fun, Y. \& Hung, J. 1997. A new measure for supplier performance evaluation. IIE transactions, 29, 753758.

Mappa, T., Edy, H. J. \& Kojong, N. 2013. Formulasi Gel Ekstrak Daun Sasaladahan (Peperomia pellucida (L.) HBK) dan Uji Efektivitasnya Terhadap Luka Bakar pada Kelinci (Oryctolagus Cuniculus). Pharmacon, 2.

Mardani, A., Jusoh, A. \& Zavadskas, E. K. 2015. Fuzzy multiple criteria decisionmaking techniques and applicationsTwo decades review from 1994 to 2014. Expert Systems with Applications, 42, 4126-4148.

Mulyadi, A. F., Wijana, S., Dewi, I. A. \& Putri, W. I. 2014. Karakteristik organoleptik produk mie kering ubi jalar kuning (Ipomoea batatas)(kajian penambahan telur dan CMC). Malang: Fakultas Teknologi Pertanian. Universitas Brawijaya.

Opricovic, S. \& Tzeng, G.-H. 2004. Compromise solution by MCDM methods: A comparative analysis of VIKOR and TOPSIS. European 
journal of operational research, 156, 445-455.

Resnawati, H. 2014. Kualitas susu pada berbagai pengolahan dan penyimpanan. JITV, 19.

Ristia, E., Daningsih, E. \& Nurdini, A. 2014. Perbandingan Kadar Gizi Tempe Biji Nangka dan Tempe Kedelai. Jurnal Pendidikan dan Pembelajaran, 3.

Roy, B. 1968. Classement et choix en présence de points de vue multiples. Revue franịaise d'informatique et de recherche opérationnelle, 2, 57-75.

Saaty, T. L. 1990. How to make a decision: the analytic hierarchy process. European journal of operational research, 48, 9-26.

Shurtleff, W. \& Aoyagi, A. 1979. The book of tempe, a super soyfood from Indonesia. Harper \& Row. New York.

Sisriyenni, D. \& Zurriyati, Y. 2014. Kajian kualitas dadih susu kerbau di dalam tabung bambu dan tabung plastik. Jurnal Pengkajian dan Pengembangan Teknologi Pertanian, 7.

Utari, D. M. 2010. Kandungan Asam Lemak, Zink, Dan Copper Pada Tempe, Bagaimana Potensinya Untuk Mencegah Penyakit Degeneratif. Gizi Indonesia, 33.

Wahyuni, R. 2011. Pemanfaatan Kulit Buah Naga Supermerah (Hylicereus Costaricensis) Sebagai Sumber Antioksidan Dan Pewarna Alami Pada Pembuatan Jelly. Jurnal Teknologi Pangan, 2, 68-85.

Widjanarko, S. B., Zubaidah, E. \& Kusuma, A. M. 2012. Studi Kualitas Fisik-Kimiawi dan Organoleptik Sosis Ikan Lele Dumbo (Clarias Gariepinus) Akibat Pengaruh Perebusan, Pengukusan dan Kombinasinya dengan Pengasapan. Jurnal Teknologi Pertanian, 4.

Winarti, S., Harmayani, E. \& Nurismanto, R. 2011. Karakteristik dan profil inulin beberapa jenis uwi (Dioscorea spp.). Agritech, 31. 